\title{
BARRIERS OF EDIBLE INSECT PURCHASE IN SPAIN AND POSSIBLE SEGMENTS (PÓSTER)
}

\author{
$\underline{\text { Kenza Goumeida }^{a}, \text { Filipa Azinheira }}{ }^{\mathrm{b}}$ and Tiziana De Magistris ${ }^{\mathrm{c}^{*}}$ \\ anstitución: Agrifood Research and Technology Centre of Aragón (Zaragoza, kgoumeida@cita-aragon.es) \\ ${ }^{b}$ Institución: Portuguese Institute of Marketing Administration (Porto, filipa.azinheira@ipam.pt) \\ 'Institución: Agrifood Research and Technology Centre of Aragón (Zaragoza, tmagistris@cita-aragon.es)
}

\begin{abstract}
Malnutrition, obesity and climate change represent the great threats for the World population which, in 2050, according to the estimates of the United Nations, will reach 9,700 million inhabitants. To mitigate this effect, the practice of eating insects (Entomophagy) is a future challenge for food, feed security and also a global concern about the global sustainable and safe utilization of resources. In line with this issue, one of the big distribution channels in Spain, Carrefour, has started to introduce edible insect food in their shelf's lines.

In contrast and despite the great advertising campaign, the sales still very low. The present study focuses on Spanish consumer's behavior for edible insects and the potential barriers preventing its consumption, in particular, we focused on an insect-made snack.

To achieve this aim, we collected 161 consumers with an online survey during Spring 2020. We used cluster and factorial analysis to profile Spanish consumers. The results confirmed that consumers did not accept the snack with insect flour in terms of organoleptic attributes and price, except for younger aged people with higher study level and income.
\end{abstract}

Keywords: Insect-based food (IBF), Sustainability, Environment, Consumers' Preferences

\section{Introduction}

Entomophagy, i.e. the eating of insects, is exercised traditionally in 113 countries all over the World Halloran et al (2018). Wild insects have been a part of the diets in human cultures around the World, and to date, more than 2111 species have been recorded as 'edible' and classified as a 'novel food' (EC 258/97) within the EU Jongema (2017).

The highest diversity of edible insect species consumed in traditional diets is found in Asia, followed by Africa and South America Kelemu et al. (2015). Current estimates of global insect consumption suggest that about 2 billion people include insects in their diet Onwezen et al. (2016) while no much evidence has been found about the eating of insects in Europe yet. Over the past few years, edible insects have moved from belonging to a large and diverse group of traditional foods with little attention from the stakeholders in the formal food system, to being claimed as the 'future of food'.

In general, edible insects were found to be good sources of proteins, fat, energy, vitamins and minerals. The consumption of $100 \mathrm{~g}$ of caterpillars, for example, provides $76 \%$ of the daily required amount of proteins and almost $100 \%$ of the daily required amount of vitamins for humans.

In comparison to conventional livestock in general, insects have a higher feed conversion efficiency it has even been indicated that insects might contribute less greenhouse gases than pig and cattle.

Concerning the safety side, not all insects are safe to eat. Just as it applies for plant and animal food products. However, all these health risks can be prevented by the consumption of common edible insect species reared on pollutant-free feed.

There are varying opinions of the role of edible insects in sustainable foods systems. Furthermore, the words 'sustainable' and 'sustainability' have often accompanied the terms 'entomophagy' and 'edible insects'. Based on the definition of the sustainable food system, edible insects from the farm to the fork is considered as a sustainable food system than other sources of protein, since it delivers food security and nutrition for all in a way that economic, social and environmental sustainability is not compromised for future generations. This food system is already challenged and will be further challenged in the future as the demand to feed the growing world population continues, where according to FAO (2013) it will reach 10 billion by 2050 . At the same time, increased consumption of foods of animal origin, urbanization, climate change and degradation of land, water and ecological systems and loss of biodiversity challenge natural resources and place further constraints on food production. 
Legislation and regulations of insect farming and value chains are unfolding in many countries because production, processing, consumption, trade and use of edible insects concern a variety of regulatory bodies, from food safety and conservation authorities to ministries of environment, health and agriculture Halloran et al. (2018).

Nowadays, wide range of commercial insect products have emerged taking different shapes and forms such as energy bars, burgers, flours and snack foods. However, consumer preferences and willingness to pay for insect-based products depend on many factors such as geographical location, consumers' perceptions and preferences of the product attributes Caparros Megido et al. (2016); Verbeke (2015); Onwezen et al. (2019).

\section{Objectives}

The general objective of this study is to investigate the Spanish consumer behavior of edible insects and the potential barriers preventing its consumption. In particular we examine consumer willingness to pay (WTP) for packaged products made of edible insects. Specifically, the Protein Bar made by Jimini's and sold by the supermarket Carrefour in the Spanish Market, which was launched in 2017.

To achieve this general objective the following specific objectives were defined:

1. Analyze economic barriers that prevent Spanish consumers to consume edible insect. Hence, we estimate the WTP for snacks made with insect flavor;

2. Analyze the best product characteristics that match with the Spanish consumer tastes (e.g., flavor, texture, ingredients);

3. Analyze personal and psychological barriers (neophobia) preventing consumers to buy edible insects-based products;

4. Analyze the availability barrier in the Carrefour Supermarket. Therefore, we identify the reliable place to situate the product on shelves, to increase its visibility.

\section{Methodology}

In order to proceed the study's main and specific objectives, we use primary data based on a survey consisted of pilot study experiment to analyze taste and price barrier using three different treatments (blind tasting, information condition, visual evaluation) for 45 subjects and an online questionnaire developed using the Qualtrics platform where the sample consisted of 200 subjects randomly chosen. In addition to this, we use also secondary information from reports, scientific articles and the data provided from Carrefour, as a basis of our study.

\section{Results}

Data was analyzed by means of statistical methods applying univariate, bivariate, factorial and cluster analysis using SPSS. Main results of the pilot study show that consumers do not accept the snack with insect flour in terms of organoleptic attributes and willingness to pay was lower than the conventional snack (54\%, $67 \%$ and $54 \%$ of subjects were willing to pay a lower price than the average price given by 1 euro in the blind, labeled and visual evolution treatments respectively).

Table 1. WTP for the three treatments

\begin{tabular}{|l|c|c|c|}
\hline & Blind test (1) & Labeled test (2) & Visual evolution (3) \\
\hline Bar with insect flour (A) & $1,00 €$ & $0,85 €$ & $1,08 €$ \\
\hline Bar free insect flour (B) & $1,20 €$ & $1,08 €$ & $1,13 €$ \\
\hline
\end{tabular}

Source: own elaboration

Consumer survey results show some logic correlations thus the consumers' personal perceptions of the insect-based products have significant influence on their knowledge.

In order to identify some possible factors that influences the following factors:

The purchasing and consumption habits of insect-based products

$\bigcirc \quad$ The attitudes toward insect-based products

O The lifestyle toward food consumption

The environmental recognition

$\bigcirc$ 
Table 2. Sociodemographic characteristics

\begin{tabular}{|c|c|c|c|}
\hline \multicolumn{2}{|c|}{ Sample size } & \multicolumn{2}{|c|}{ Age (\%) } \\
\hline & & $20-34$ & $29 \%$ \\
\hline \multicolumn{2}{|c|}{ Gender (\%) } & $35-54$ & $52 \%$ \\
\hline Male & $40 \%$ & $55<$ & $19 \%$ \\
\hline Female & $60 \%$ & \multicolumn{2}{|c|}{ Subject monthly income (\%) } \\
\hline \multicolumn{2}{|c|}{ Level of study (\%) } & Less than $900 €$ & $6 \%$ \\
\hline No study & $1 \%$ & $900 €-1500 €$ & $16 \%$ \\
\hline Primary & $1 \%$ & $1501 €-2500 €$ & $24 \%$ \\
\hline Secondary & $13 \%$ & $2501 €-3500 €$ & $34 \%$ \\
\hline University & $84 \%$ & $3501 €-4500 €$ & $10 \%$ \\
\hline & & More than 4501€ & $10 \%$ \\
\hline
\end{tabular}

Source: own elaboration

A factorial analysis was conducted, where we obtained a correlation matrix that represents the variance of the total variables and covariance between pairs of all the variables, furthermore we confirm that data were correlated using KMO and Bartlett's test.

Results of this analysis are summarized in table 3 and it yielded a solution of a number of factors for each variable previously mentioned.

Table 3. Summary of factorial analysis

\begin{tabular}{|c|c|c|}
\hline Variables & Factors & Cumulative variance \\
\hline \multirow{3}{*}{$\begin{array}{l}\text { The purchasing and } \\
\text { consumption habits of insect- } \\
\text { based products }\end{array}$} & Food Safety & $42,748 \%$ \\
\hline & Availability on Store & $60,196 \%$ \\
\hline & Price & $76,896 \%$ \\
\hline \multirow{2}{*}{$\begin{array}{l}\text { The attitudes toward insect } \\
\text { products }\end{array}$} & Nutrition and Environment & $36,712 \%$ \\
\hline & IBF Acceptance & $55,719 \%$ \\
\hline \multirow{3}{*}{$\begin{array}{l}\text { The scale of neophobia towards } \\
\text { consumption of insect-based } \\
\text { products }\end{array}$} & Fear of trying new food & $36,609 \%$ \\
\hline & New Food Desire & $58,550 \%$ \\
\hline & Trust on new experience & $75,343 \%$ \\
\hline \multirow{3}{*}{$\begin{array}{l}\text { Consumers' lifestyle towards } \\
\text { food }\end{array}$} & Healthy Diet & $24,067 \%$ \\
\hline & Balanced Diet & $42,501 \%$ \\
\hline & Vegetarian Consumers & $57,487 \%$ \\
\hline The environmental recognition & Environmentally Friendly & $60,649 \%$ \\
\hline
\end{tabular}

Source: own elaboration

Concerning market segmentation four (4) segments had been identified. Where the first group of consumer represents the $(20.95 \%)$ of the total sample, the second cluster is the biggest one and it represents the $(37.83 \%)$. The third group is the smallest one with $(16.22 \%)$ and cluster four represents the $(25 \%)$ of the entire sample. The different results analysis and corresponding interpretation lead to the conclusion that the consumption of Insect Based Food (IBF) in Spain tend to be almost absent. Despite the presence of barriers (Price, availability) preventing subjects to be a potential consumer however, it was a minority of consumers that are familiar already with it were younger aged, with high study level with high income in addition they had some barriers (Table 4).

Table 4. Cluster centers to identify the membership in each group

\begin{tabular}{|l|c|c|c|c|}
\hline & \multicolumn{4}{|c|}{ Clusters } \\
\hline \multicolumn{1}{|c|}{ Identified factors } & $\mathbf{1}$ & $\mathbf{2}$ & $\mathbf{3}$ & $\mathbf{4}$ \\
\hline IBF- Acceptance &, 35641 &,$- 79502^{*}$ &, 33371 &,$- 73863^{*}$ \\
\hline Trust on new experience & $1,43922^{*}$ &,- 53547 &, $85592^{* *}$ &, 58241 \\
\hline Balanced Diet & $-1,06255^{*}$ &, $22113^{* *}$ &, $74930^{* *}$ &, 51068 \\
\hline Vegetarian Consumers &, $41321^{*}$ &,$- 65999^{*}$ &,$- 11508^{*}$ & $3,25762^{* *}$ \\
\hline Environmentally Friendly &,$- 31888^{*}$ &,- 21722 &, 39844 &,- 29553 \\
\hline
\end{tabular}

*Least important factor **Most important factor

Source: own elaboration 


\section{Conclusions}

To conclude, due to the high protein content of insect-based food, they could supplement the conventional production of meat for direct human consumption or for indirect use as feedstock in the face of an increasing world population and quest for alternative protein sources. As recommendation, Carrefour need s to invest in social media and communication campaigns to improve consumer's knowledge on insects-based products (environment, sustainability, health, nutrition, etc.), also an improvement of the products attribute can provide a solution for consumers who don't accept the product. Also, an adaptation of the market strategy based on the market segmentation realized.

\section{Bibliography}

Caparros Megido, R., Gierts, C., Blecker, C., Brostaux, Y., Haubruge, É., Alabi, T., \& Francis, F. (2016). Consumer acceptance of insect-based alternative meat products in Western countries. Food Quality and Preference, 52, 237-243. https://doi.org/10.1016/j.foodqual.2016.05.004

FAO. (2013). Edible insects. Future prospects for food and feed security. Food and Agriculture Organization of the United Nations (Vol. 171).

Halloran, A., Flore, R., Vantomme, P., \& Roos, N. (2018). Edible Insects in Sustainable Food Systems. Edible Insects in Sustainable Food Systems. https://doi.org/10.1007/978-3-319-74011-9

Jongema, Y. (2017). List of edible insects of the world. Retrieved May 8, 2021, from http://bit.ly/1wbQojQ

Kelemu, S., Niassy, S., Torto, B., Fiaboe, K., Affognon, H., Tonnang, H., ... Ekesi, S. (2015). African edible insects for food and feed: Inventory, diversity, commonalities and contribution to food security. Journal of Insects as Food and Feed, 1(2), 103-119. https://doi.org/10.3920/JIFF2014.0016

Onwezen, M. C., van den Puttelaar, J., Verain, M. C. D., \& Veldkamp, T. (2019). Consumer acceptance of insects as food and feed: The relevance of affective factors. Food Quality and Preference. https://doi.org/10.1016/j.foodqual.2019.04.011

Onwezen, M., Verain, M., Puttelaar, J. van den, \& Bouwman, E. (2016). Eating insects. How to make it the new normal, 1-6.

Verbeke, W. (2015). Profiling consumers who are ready to adopt insects as a meat substitute in a Western society. Food Quality and Preference, 39, 147-155. https://doi.org/10.1016/j.foodqual.2014.07.008 